\title{
ANTIDIABETIC EFFECTS OF PUMPKIN (CUCURBITA MOSCHATA DURCH) FLESH AND SEEDS EXTRACTS IN STREPTOZOTOCIN INDUCED MICE
}

\author{
NOVARIANTI MARBUN ${ }^{1 *}$, PANAL SITORUS ${ }^{1}$, SITI MORIN SINAGA ${ }^{2}$ \\ ${ }^{1}$ Department of Biological Pharmacy, Faculty of Pharmacy, University of Sumatera Utara, Medan, Indonesia. ${ }^{2}$ Department of \\ Pharmaceutical Chemistry, Faculty of Pharmacy, University of Sumatera Utara, Medan, Indonesia. Email: marbun.nova1987@yahoo.com
}

Received: 17 August 2017, Revised and Accepted: 27 October 2017

\section{ABSTRACT}

Objective: The present study is to investigate the antidiabetic effect of pumpkin flesh and seeds ethanolic extracts in STZ-induced diabetic mice.

Methods: The study begins with making the ethanolic extracts of pumpkin flesh and seeds and then evaluates the physicochemical characterization, phytochemical screening, and induced diabetic mice using STZ.

Result: The physicochemical evaluation shows that the extracts had a good and high purity level, while the phytochemical screening showed both pumpkin flesh and seeds extracts have a various of phytoconstituents. The pumpkin flesh and seeds ethanolic extracts (dose level $150 \mathrm{mg} / \mathrm{kg}$ ) showed a significant reduction of the blood glucose.

Conclusion: Pumpkin flesh and seeds ethanolic extracts exhibited significant antidiabetes activity in STZ-induced mice.

Keywords: Antidiabetic, Diabetes mellitus, Pumpkin, Streptozotocin, Mice.

(C) 2018 The Authors. Published by Innovare Academic Sciences Pvt Ltd. This is an open access article under the CC BY license (http://creativecommons. org/licenses/by/4. 0/) DOI: http://dx.doi.org/10.22159/ajpcr.2018.v11i2.22023

\section{INTRODUCTION}

Diabetes mellitus (DM) is a chronic disorder of carbohydrate, fat, and protein metabolism. The disease is characterized by the high levels of blood glucose due to the absence of insulin or insulin resistance [1-3]. In the present day, there is a global increase in the prevalence of DM which related to the lifestyle and obesity [4]. Since type 2 DM is predicted to increase significantly in the next few years, its prevention and treatment have urgent priority. World Health Organization (WHO) has a projection that the prevalence of DM will increase to 370 million or more by the year 2030 [5].

The current epidemic of DM in the world, clearly indicates the urgent need to develop the new therapeutic drugs of cheaper and more safety and available to face this health challenge. In spite of the availability of various antidiabetic agents and its secondary complications continue to become a major problem in the world population, medicinal plants and their bioactive compound are used as an alternative method to treat the diabetes patient throughout the world and popular as nutraceutical [6,7]. There is considerable need for safe agents that can reduce side effect for the DM patient. Although certain drugs (such as metformin, acarbose, and orlistat) have shown DM-preventive activity in large randomized studies, nutraceuticals have a good potential in this regard as well [8]. A number of plant products among which the protein-rich seeds including Citrullus lanatus, Cucurbita moschata, Lagenaria siceraria, and Cucumeropsis mannii are commonly used in traditional medicine against DM $[9,10]$.

Pumpkin or C. moschata Durch is an important horticultural crop that belongs to family Cucurbitaceae. Pumpkin fruit is one of the widely grown vegetables that are incredibly rich in vital antioxidants and vitamin. This humble backyard low-calorie vegetable contains Vitamin A, flavonoid polyphenolic antioxidants such as lutein, xanthin, and carotenes in abundance [11,12]. Pumpkin is a traditional vegetable in many countries and is believed to have a lot of health benefits such as anticancer, antioxidant, antihyperlipidemic, and antimicrobial [13-16].
Chinese people believe that pumpkin can be used to treat DM. The aim of this study was to evaluate the antidiabetic effect of $C$. moschata Durch using the extracts of pumpkin flesh and seeds from ethanol solvent in STZ-induced diabetic mice.

\section{METHODS}

\section{Plant collection and identification}

Fresh pumpkin flesh and seeds were collected from local area of Galang and authenticated by the Indonesian Institute of Sciences: Research Center for Biology.

\section{Plant extraction preparation}

The dried pumpkin flesh and seeds (1 $\mathrm{kg}$ for each) was extracted by maceration method using an organic solvent (ethanol) for 7 days. The maceration of pumpkin flesh and seeds extracts, then filtered continuously until the filtrate obtained is clear and colorless.

\section{Physicochemical evaluation}

Analysis of physicochemical constants of the pumpkin flesh and seeds extracts has been performed to evaluate the quality and purity of the herbal drugs. Various physicochemical parameters such as total ash value, acid insoluble ash value, moisture content, alcohol, and watersoluble extractive value were calculated as per the WHO and Indonesia Materia Medica guidelines [17,18].

\section{Preliminary phytochemical screening}

The ethanolic extracts of yellow pumpkin flesh and seeds were subjected to preliminary phytochemical screening for examining various chemical secondary metabolites such as alkaloids, saponins, flavonoids, tannins, triterpenoids, and steroids $[19,20]$.

\section{Preparation of animals}

Healthy adult male mice (20-35 g body weight) from animal house of Faculty of Pharmacy, University of Sumatera Utara, were used for the study. The use of animals was approved by "Animal Research Ethics Committees (AREC) of University of Sumatera Utara (AREC Reg. No: 
Table 1: Physicochemical evaluation result

\begin{tabular}{llllll}
\hline \multirow{2}{*}{ Pumpkin } & \multicolumn{2}{l}{ Physicochemical evaluation } & & \\
\cline { 2 - 6 } & Total Ash value (\%) & Acid insoluble Ash (\%) & Moisture content (\%) & \multicolumn{2}{l}{ Extractive soluble values } \\
\cline { 4 - 6 } & & & 3.33 & Alcohol (\%) & Water (\%) \\
\hline Flesh extract & 6.34 & 0.56 & 1.19 & 50.08 & 72.09 \\
Seeds extract & 1.45 & 0.09 & 54.92 & 40.82 \\
\hline
\end{tabular}

796/KEPH-FMIPA/2016)." Mice were housed in a polycarbonate cages under room temperature $\left(20 \pm 2^{\circ} \mathrm{C}\right)$, relative humidity $(60-70 \%)$ and were exposed to $12 \mathrm{~h}$ day-night circle. They were fed on a standard pellet diet and water ad libitum.

\section{Experimental design}

Experimental diabetes was induced by single intraperitoneal injection of $55 \mathrm{mg} / \mathrm{kg}$ of STZ, freshly dissolved in citrate buffer ( $\mathrm{pH} 4.5)$. After 3 days of STZ injection, mice with fasting glucose above $200 \mathrm{mg} / \mathrm{dl}$ were considered as diabetic and included in the study (Marbun, 2017).

The animals were divided into five groups of three animals for each group were used in this experiment:

Group I: Normal control animals are given normal pellet and CMC $0.5 \% \mathrm{~b} / \mathrm{v}$.

Group II: Diabetic mice.

Group III: Mice were induced by STZ and treated with metformin $(65 \mathrm{mg} / \mathrm{kg})$.

Group IV: Mice were induced by STZ and treated with ethanolic pumpkin flesh extract $(150 \mathrm{mg} / \mathrm{kg})$.

Group V: Mice were induced by STZ and treated with ethanolic pumpkin seeds extract $(150 \mathrm{mg} / \mathrm{kg})$.

The extract was given daily through oral way for a period of 15 days.

\section{Statistical analysis}

The glucose levels were determined by triplicates and expressed as a mean \pm standard error of mean. The significant difference of data between different groups was compared by ANOVA followed by Duncan's test

\section{RESULTS}

Physicochemical evaluation

Table 1 summarizes the result of physicochemical evaluation from pumpkin flesh and seeds extracts.

Phytochemical screening of pumpkin flesh and seeds ethanolic extracts

Screening results of pumpkin flesh and seeds ethanolic extract showed different chemical compound in the different extract. The results can be shown in Table 2.

Effect of pumpkin flesh and seeds ethanolic extracts on diabetic mice

STZ induced diabetic mice exhibiting persistent the diabetes or hyperglycemia was selected for the assessing the effect of pumpkin flesh and seeds ethanolic extract (blood glucose $>200 \mathrm{mg} / \mathrm{dl}$ ). Table 3 and Fig. 1 show the level of blood glucose at various intervals to observe the effect of different treatment using pumpkin flesh and seeds extracts and metformin

\section{DISCUSSION}

The result of physicochemical evaluation shows that the extracts were made with a good quality and high purity level, which accepted by the WHO, while the phytochemical screening results show that the ethanolic extracts of pumpkin flesh and seeds revealed the presence of
Table 2: Phytochemical screening result of pumpkin flesh and seeds extract

\begin{tabular}{lll}
\hline Screening & Ethanolic extracts & \\
\cline { 2 - 3 } & Pumpkin flesh & Pumpkin seeds \\
\hline Alkaloids & Negative & Negative \\
Flavonoids & Positive & Positive \\
Saponins & Positive & Positive \\
Tannins & Positive & Positive \\
Triterpenoid/steroids & Positive & Positive \\
\hline
\end{tabular}

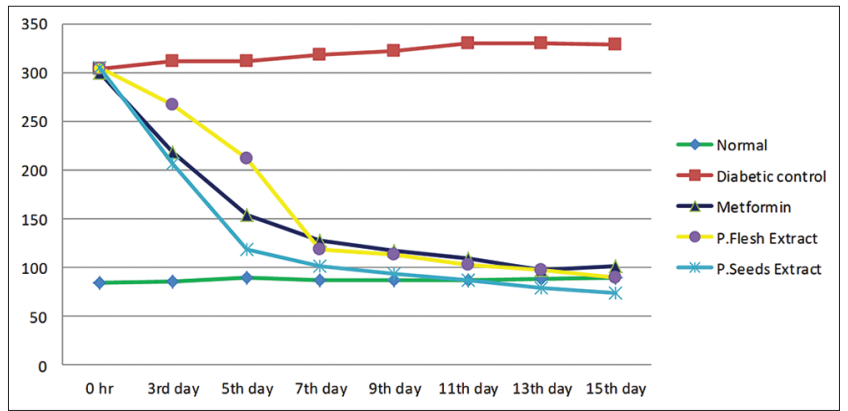

Fig. 1: Effect of pumpkin flesh and seeds ethanolic extract on blood glucose level in diabetic mice $(\mathrm{mg} / \mathrm{dl})$

many phytochemical constituents such as flavonoids, tannis, steroids, terpenoids, and saponins.

STZ or streptozotocin is a potent diabetogenic agent and widely used for inducing the diabetes in a variety of animal models. STZ destroys the pancreatic insulin secreting $\beta$-cells, resulting in a disease in insulin release which can make DM. The antidiabetes results indicated that the ethanolic extract of pumpkin flesh and seeds showed a significant antidiabetic activity which almost the same as metformin. The high antidiabetic effect of these extracts was probably due to the presence of several chemical compounds and their synergistic properties effect. The possible mechanism by which pumpkin brings out its antidiabetic action maybe potentiating and stimulate the insulin secretion from pancreatic $\beta$-cells [21]. Another possibility is because the flavonoids can protect the DNA from the oxidative damage, so it can resist the problem in $\beta$-cell [22-24].

\section{CONCLUSIONS}

C. moschata Durch flesh and seeds extracts produced significant blood glucose reducing effect in diabetic mice. Both of flesh and seeds extract could lower the glucose levels to the normal state. Therefore, this extract could be used in the pharmaceutical industry for development of drug formulations.

\section{ACKNOWLEDGEMENTS}

This work and publication were supported by The Faculty of Pharmacy and Iksen, S.Farm., M.Si 
Table 3: Effect of pumpkin flesh and seeds ethanolic extracts on blood glucose level in diabetic mice

\begin{tabular}{|c|c|c|c|c|c|c|c|c|}
\hline \multirow[t]{2}{*}{ Group } & \multicolumn{8}{|c|}{ Blood glucose level (mg/dl) } \\
\hline & $\mathbf{0 ~ h}$ & $3^{\text {rd day }}$ & $5^{\text {th }}$ day & $7^{\text {th }}$ day & $9^{\text {th }}$ day & $11^{\text {th }}$ day & $13^{\text {th }}$ day & $15^{\text {th }}$ day \\
\hline I & $84 \pm 5.34$ & $86 \pm 3.92$ & $89.67 \pm 3.54$ & $86.67 \pm 5.81$ & $87.33 \pm 5.60$ & $87 \pm 3.93$ & $88 \pm 6.09$ & $89.06 \pm 6.37$ \\
\hline III & $300 \pm 3.1$ & $217.6 \pm 4.3^{* *}$ & $154.3 \pm 4.13^{* *}$ & $127.6 \pm 4.17^{* *}$ & $116.67 \pm 3.92^{* *}$ & $108.67 \pm 6.51^{* *}$ & $103.33 \pm 2.25^{* *}$ & $100.67 \pm 6.09 * *$ \\
\hline IV & $304.33 \pm 2.99$ & $266.67 \pm 3.87 * *$ & $212 \pm 3.05^{* *}$ & $118.33 \pm 6.43^{* *}$ & $113 \pm 2.90^{* *}$ & $102.67 \pm 6.28^{* *}$ & $96.67 \pm 1.37^{* *}$ & $89.33 \pm 2.99^{* *}$ \\
\hline V & $304.67 \pm 4.1$ & $206 \pm 2.1^{* *}$ & $118.33 \pm 3.89 * *$ & $101.67 \pm 5.34^{* *}$ & $93 \pm 4.65^{* *}$ & $86.33 \pm 7,21^{* *}$ & $79.33 \pm 7.77^{* *}$ & $74.33 \pm 3.6^{* *}$ \\
\hline
\end{tabular}

\section{AUTHORS COCONTRIBUTIONS}

All the authors have contributed equally.

\section{CONFLICT OF INTERESTS}

None declared.

\section{REFERENCES}

1. Marbun N. Comparison of Blood Glucose Levels Decrease Effectiveness of Pumpkin Flesh and Seeds Toward Diabetic Mice, Thesis, Faculty of Pharmacy, University of Sumatera Utara; 2017. p. 1-106.

2. Zhang Y, Wu L, Ma Z, Cheng J, Liu J. Anti-diabetic, anti-oxidant and anti-hyperlipidemic activities of flavonoids from corn silk on STZinduced diabetic mice. Molecules 2015;21:E7.

3. Parthasarathy R, Illavarasan R, Karrunakaran CM. Antidabetic activity of Thespesia populnea bark and leaf extrct against streptozotocin induced diabetic rats. Int J Pharmtech Res 2009;1:1069-72.

4. King H, Aubert RE, Herman WH. Global burden of diabetes, 19952025: Prevalence, numerical estimates, and projections. Diabetes Care 1998;21:1414-31.

5. WHO. Definition and Diagnosis of Diabetes Mellitus and Intermediate Hyperglycemia. Geneva: WHO; 2006. p. 1-50.

6. Rumanti RM. Characterization of Simplicia and Chromatographic Analysis of Active Extract Lotus (Nelumbo nucifera Gaertn) which can Reduce Blood Glucose in Mice, Thesis, Faculty of Pharmacy, University of Sumatera Utara; 2017. p. 1-104.

7. Lal VK, Gupta PP, Awanish P. Hypoglycemic effect of Kyllinga trceps in STZ induced diabetic rats. J Diabetes Metab 2012;3:1-3.

8. McCarty MF. Nutraceutical resources for diabetes prevention-an update. Med Hypotheses 2005;64:151-8.

9. Teugwa CM, Boudjeko T, Tchinda BT, Mejiato PC, Zofou D. Antihyperglycaemic globulins from selected Cucurbitaceae seeds used as antidiabetic medicinal plants in Africa. BMC Complement Altern Med 2013;13:63

10. Sani UM. Phytochemical screening and antidiabetic effect of extracts of the seeds of Citrullus lanatus in alloxan-induced diabetic albino mice. J Appl Pharm Sci 2015;5:51-4.

11. Taylor MJ, Brant J. Trends in World Cucurbit Production, 1991-2001.
Alexandria: ASHS Press; 2002. p. 373-9.

12. Zhao YM, Li XZ, Zhou JG. Worldwide production and diversity characteristics of Cucurbita species. J Inn Mongolia Agric Univ 2004; 15:238-41.

13. Ting Z, Qian K, Jingrong H, Ruitong D, Quanhong L. Characterization of nutritional components and utilization of pumpkin. Food 2007; 1:313-21.

14. Elella FA, Mourad R. Anticancer and anti-oxidant potentials of ethanolic extracts of Phoenix dactylifera, Musa acuminata, and Cucurbita maxima. Res J Pharm Biol Chem Sci 2015;6:710-20.

15. Sharma A, Sharma AK, Chand T, Khardiya M, Yadav KC. Antidiabetic and antihyperlipidemic activity of Cucurbita maxima (Pumpkin) seeds on streptozotocin induced diabetic rats. J Pharmacogn Phytochem 2013;1:108-16.

16. Muruganantham N, Solomon S, Senthamilselvi MM. Antimicrobial activity of Cucurbita maxima flowers (Pumpkin). J Pharmacogn Phytochem 2016;5:15-8.

17. World Health Organization, WHO. Quality Control Methods for Medicinal Plant Materials, WHO/PHARM/92.559. Geneva: WHO; 1998. p. 4-46.

18. Depkes RI. Materia Medika. Vol. 6. Jakarta: Ditjen POM; 1995. p. 297-307.

19. Farnsworth NR. Biological and phytochemical screening of plants. J Pharm Sci 1966;55:225-76.

20. Harbone JB. Metode Fitokimia. Vol. 2. Bandung: Penerbit ITB; 1987. p. 49.

21. Tiedge M, Lenzen S. Effects of glucose refeeding and glibenclamide treatment on glucokinase and GLUT2 gene expression in pancreatic B-cells and liver from rats. Biochem J 1995;308:139-44.

22. Mujic A, Grdovic N, Mujic I, Mihailovic M, Zivkovic J, Poznanovic G, et al. Antioxidative effects of phenolic extracts from chestnut leaves, catkins and spiny burs in streptozotocin-treated rat pancreatic $\beta$-cells. Food Chem 2011;125:841-9.

23. Kabbaoui ME, Chda A, Mejrhit N, Azdad O, Farah A, Aarab L, et al. Antidiabetic effect of Thymus satureioides aqueous extract in streptozotocin-induced diabetic rats. Int $\mathrm{J}$ Pharm Pharm Sci 2016;8:140-5.

24. Bharathi TR, Prakash HS. Comparative evaluation of antidiabetic and antioxidant potency of different extracts obtained from Memecylon species. Int J Pharm Pharm Sci 2017;9:187-91. 